\title{
Seizure-related 6 homolog like 2 autoimmunity
}

Neurologic syndrome and antibody effects

Jon Landa, MSc,* Mar Guasp, MD,* Mar Petit-Pedrol, PhD, Eugenia Martínez-Hernández, MD, PhD, Jesús Planagumà, PhD, Albert Saiz, MD, PhD, Raquel Ruiz-García, PhD, Lorena García-Fernández, MD, Jan Verschuuren, MD, PhD, Rachel Saunders-Pullman, MD, MPH, Liliana Ramirez-Gómez, MD,

Michael D. Geschwind, MD, PhD, Josep Dalmau, MD, PhD, Lidia Sabater, PhD, $†$ and Francesc Graus, MD, PhD $\dagger$

Neurol Neuroimmunol Neuroinflamm 2021;8:e916. doi:10.1212/NXI.0000000000000916

\section{Abstract \\ Objective}

To describe the clinical syndrome of 4 new patients with seizure-related 6 homolog like 2 antibodies (SEZ6L2-abs), study the antibody characteristics, and evaluate their effects on neuronal cultures.

\section{Methods}

SEZ6L2-abs were initially identified in serum and CSF of a patient with cerebellar ataxia by immunohistochemistry on rat brain sections and immunoprecipitation from rat cerebellar neurons. We used a cell-based assay (CBA) of HEK293 cells transfected with SEZ6L2 to test the serum of 95 patients with unclassified neuropil antibodies, 331 with different neurologic disorders, and 10 healthy subjects. Additional studies included characterization of immunoglobulin G (IgG) subclasses and the effects of SEZ6L2-abs on cultures of rat hippocampal neurons.

\section{Results}

In addition to the index patient, SEZ6L2-abs were identified by CBA in 3/95 patients with unclassified neuropil antibodies but in none of the 341 controls. The median age of the 4 patients was 62 years (range: 54-69 years), and 2 were female. Patients presented with subacute gait ataxia, dysarthria, and mild extrapyramidal symptoms. Initial brain MRI was normal, and CSF pleocytosis was found in only 1 patient. None improved with immunotherapy. SEZ6L2abs recognized conformational epitopes. IgG4 SEZ6L2-abs were found in all 4 patients, and it was the predominant subclass in 2. SEZ6L2-abs did not alter the number of total or synaptic SEZ6L2 or the AMPA glutamate receptor 1 (GluA1) clusters on the surface of hippocampal neurons.

\section{Conclusions}

SEZ6L2-abs associate with a subacute cerebellar syndrome with frequent extrapyramidal symptoms. The potential pathogenic effect of the antibodies is not mediated by internalization of the antigen.

\author{
Correspondence \\ Dr. Graus \\ francesc.graus@idibaps.org
}




\section{Glossary}

CBA = cell-based assay; IgG = immunoglobulin G; MuSK = muscle-specific kinase .

The identification of autoantibodies against neuronal cell surface antigens in patients with predominant or isolated cerebellar ataxia has progressed more slowly compared with the discovery of antibodies in the field of autoimmune encephalitis. ${ }^{1,2}$ However, characterization of these type of antibodies is important because they identify potentially treatable autoimmune neurologic syndromes that otherwise are misdiagnosed. In 2014, seizure-related 6 homolog like 2 antibodies (SEZ6L2-abs) were identified in a patient with subacute cerebellar ataxia and retinopathy and later in another patient with progressive cerebellar ataxia associated with hypomimia, bradykinesia, and postural instability. ${ }^{3,4}$ SEZ6L2 (also known as BSRPA, for brain-specific receptor-like protein A) is a type 1 transmembrane protein highly expressed in the brain, particularly in the hippocampus and cerebellum, and in many types of cancer. ${ }^{5,6}$ Triple knockout mice in SEZ6, SEZ6L, and SEZ6L2 (the seizure-related gene 6 family) have motor discoordination and abnormal innervation of Purkinje cells by climbing fibers in the cerebellum. ${ }^{7}$ Studies on cell lines (HeLa or HEK293) transfected with SEZ6L2 and $\alpha$-amino-3-hydroxy-5-methyl4-isoxazolepropionic acid (AMPA) glutamate receptor 1 (GluA1) showed that these 2 proteins are binding partners, and the interaction between both is key for neural cell signal transduction via the adducing protein pathway. ${ }^{8}$ Furthermore, antibodies from the first reported patient inhibited the physiologic interaction of SEZ6L2 with GluA1 and impaired the AMPA receptor signaling pathway. ${ }^{9}$ Here, we report the clinical and immunologic features of 4 additional patients with SEZ6L2-abs and evaluate the antibody effects on cultures of live rat hippocampal neurons.

\section{Methods}

\section{Standard protocol approvals, registrations, and patient consents}

The Ethics Committee of the Hospital Clinic approved the study. All patients or proxies gave written informed consent for the storage and use of serum, CSF, and clinical information for research purposes.

\section{Patients}

The observation that the serum and CSF of a patient, described in detail below, with subacute gait ataxia, postural instability, and frequent falls, reacted with the neuropil of rat brain and cell surface of cultured rat hippocampal neurons led us to immunoprecipitate SEZ6L2. Then, we retrospectively analyzed the presence of SEZ6L2-abs by cell-based assay (CBA) of HEK293 cells transfected with SEZ6L2 in the serum of 95 patients with unclassified immunoreactivities against rat brain neuropil, disclosing 3 additional positive patients. Investigators that selected these 95 cases with unclassified neuropil reactivities were blinded to clinical information. SEZ6L2-abs were also tested in the serum of 10 healthy blood donors and 331 patients with the following neurologic diagnosis: multiple system atrophy with predominant cerebellar phenotype (76), paraneoplastic cerebellar degeneration (62), nonhereditary degenerative ataxia (60), MS (61), neuromyelitis optica spectrum disorder (10), progressive supranuclear palsy (29), opsoclonus-myoclonus syndrome (20), and Creutzfeldt-Jakob disease (13).

\section{Immunoprecipitation and mass spectrometry}

Cultures of rat cerebellar granular neurons were obtained as previously described. ${ }^{10}$ For the immunoprecipitation experiments, neurons were incubated with $300 \mu \mathrm{L}$ of patient or control CSF for 1 hour at $37^{\circ} \mathrm{C}$, washed, lysed, centrifuged, and the supernatant incubated with $60 \mu \mathrm{L}$ of $\mathrm{A} / \mathrm{G}$ beads (20423, Thermo Fisher Scientific, Waltham, MA) and incubated overnight at $4^{\circ} \mathrm{C}$. After extensive washing, beads were cleaned 3 times with $500 \mu \mathrm{L}$ of $200 \mathrm{mM}$ ammonium bicarbonate (09830, Sigma-Aldrich, St. Louis, MO) and $60 \mu \mathrm{L}$ of $6 \mathrm{M}$ Urea (17-1319-01, Sigma-Aldrich). Samples were then reduced with dithiothreitol $\left(30 \mathrm{nmol}, 37^{\circ} \mathrm{C}, 60\right.$ minutes; D9163, Sigma-Aldrich), alkylated in the dark with iodoacetamide ( $60 \mathrm{nmol}, 25^{\circ} \mathrm{C}, 30$ minutes; I1146, Sigma-Aldrich), and diluted to $1 \mathrm{M}$ urea with $200 \mathrm{mM}$ ammonium bicarbonate for digestion with trypsin $\left(1 \mu \mathrm{g}, 37^{\circ} \mathrm{C}, 8\right.$ hours; V5111, Promega, Madison, WI). The peptide mix was acidified with formic acid, desalted with a MicroSpin C18 column (SUM SS18V, The Nest Group, Southborough, MA), and analyzed using a LTQ-Orbitrap Velos Pro mass spectrometer (Thermo Fisher Scientific) coupled to an EASY-nLC 1000 (Thermo Fisher Scientific). Peptides were loaded onto the 2-cm Nano Trap column and were separated by reversed-phase chromatography (Nikkyo Technos Co., Ltd. Japan). The mass spectrometer was operated in positive ionization mode with nanospray analyzer. All data were acquired with Xcalibur software v2.2. Digested bovine serum albumin (P8108S, New England Biolabs, Ipswich, MA) was analyzed between each sample to avoid sample carryover. Acquired spectra were analyzed using the Proteome Discoverer software suite (v1.4, Thermo Fisher Scientific) and the Mascot search engine (v2.6, Matrix Science ${ }^{2}$ ). The data were searched against a Swiss-Prot human plus NCBInr Rat database.

\section{Immunohistochemistry, immunocytochemistry on HEK293 cells, and evaluation of IgG subclasses}

Patients' antibody reactivity in serum (1:200) and CSF (1:5) was assayed on: (1) frozen sections of rat brain postfixed with paraformaldehyde (PFA) using a standard avidin-biotin peroxidase method; (2) CBA with HEK293 cells transfected with MYC-DDK-tagged SEZ6L2 human clone (catalog number 
RC224059, accession number NM_012410 Origene, Rockville, $\mathrm{MD}$ ). Cells were incubated with patients' serum or CSF for 1 hour at room temperature, fixed in $4 \%$ paraformaldehyde, permeabilized with $0.3 \%$ Triton X-100 and incubated with MYC-tag antibody (2276S, Cell Signaling Technology, Danvers, MA) following corresponding fluorescent secondary antibodies; and (3) rat hippocampal and cerebellar granular neurons using an indirect immunofluorescence method as in the CBA. All these procedures have been previously published in detail. ${ }^{10-12}$

Analysis of SEZ6L2 immunoglobulin G (IgG) subclasses was performed by indirect immunofluorescence on HEK293 cells transfected with SEZ6L2 incubated with serial dilutions of patient's serum or CSF followed by specific fluoresceinconjugated secondary antibodies against the 4 human IgG classes (1:500; IgG1-IgG4, The Binding Site, Birmingham, England) and processed as previously described. ${ }^{13}$

\section{Immunoprecipitation of HEK293 cells and Western blot assays}

To confirm the specificity of SEZ6L2-abs detected by the CBA, nonpermeabilized HEK293 cells transfected with SEZ6L2 were incubated with patients' or control serum (1: 100) for 1 hour at $37^{\circ} \mathrm{C}$, washed, lysed, centrifuged, and the supernatant incubated with protein $\mathrm{A} / \mathrm{G}$ agarose beads. After centrifugation, the pellet containing the beads with the proteins bound to the serum antibodies from patients or controls was washed and the proteins separated electrophoretically and transferred to a nitrocellulose membrane (1704158, BioRad, Hercules, CA) that was sequentially incubated with MYC-tag commercial antibody, the appropriate secondary antibody, and developed following a standard enhanced chemiluminescence developing kit (RPN2108, GE Healthcare, Chicago, IL).

To determine whether patients' SEZ6L2-abs recognized lineal epitopes, lysates of HEK293 cells transfected with SEZ6L2 were subjected to electrophoresis under denaturing conditions, transferred to a nitrocellulose membrane, and incubated with patient's serum (1:500). A commercial antibody that recognizes a lineal epitope of SEZ6L2 (1:500; PA5-64172, Thermo Fisher Scientific) was used as a positive control.

\section{Cultures of neurons, antibody effects on SEZ6L2, and confocal microscopy}

Cultures of rat hippocampal neurons were prepared from isolated rat hippocampi of E18 embryos. ${ }^{12}$ After 14 days, CSF of patient 4, who had predominantly IgG1 SEZ6L2-abs, or control (1:20 in culture medium) was added to the culture media for either 24 or 72 hours. After removing the media and extensively washing with phosphate buffered saline, neurons were live incubated with serum from patient 4 (1:200) for 1 hour at $37^{\circ} \mathrm{C}$ to stain and visualize the clusters on the cell surface. Subsequently, neurons were fixed with 4\% PFA for 10 minutes, incubated with Alexa Fluor 488 goat antihuman $\operatorname{IgG}$ (1:1000, 109-545-088, Jackson ImmunoResearch, Newmarket, UK) for 1 hour at room temperature, and permeabilized with $0.3 \%$ Triton for 5 minutes. This was followed by incubation with a rabbit anti-PSD95 antibody (1:200, ab18258, Abcam, Cambridge, UK) for 1 hour and incubation with Alexa Fluor 594 goat anti-rabbit IgG (1:1000, A-11012, Thermo Fisher Scientific). The same experiment was performed in parallel with a sample with NMDA autoantibodies as a control for internalization. ${ }^{12}$

To evaluate the effects of SEZ6L2-abs on GluA1, treatments were performed on hippocampal neurons for 72 hours. Anti-

Table Clinical features and outcome of 4 patients with SEZ6L2 antibodies

\begin{tabular}{|c|c|c|c|c|}
\hline Patient (age/sex) & $1(69 / M)$ & $2(55 / F)$ & $3(54 / M)$ & $4(69 / F)$ \\
\hline Time to $\mathrm{mRS} 3$ & $2 \mathrm{mo}$ & $3 \mathrm{mo}$ & $4 \mathrm{mo}$ & $3 \mathrm{mo}$ \\
\hline $\begin{array}{l}\text { Main symptoms } \\
\text { at onset }\end{array}$ & $\begin{array}{l}\text { Gait ataxia, postural instability, and } \\
\text { frequent falls }\end{array}$ & $\begin{array}{l}\text { Gait ataxia, dizziness, and mild } \\
\text { cognitive impairment }\end{array}$ & Dysarthria and gait ataxia & $\begin{array}{l}\text { Gait ataxia and } \\
\text { dysarthria }\end{array}$ \\
\hline Dysarthria & Yes & Yes & Yes & Yes \\
\hline Gait ataxia & Yes & Yes & Yes & Yes \\
\hline Limb ataxia & No & Yes & Yes & Yes \\
\hline Cognition & $\begin{array}{l}\text { Bradypsychia, echolalia, and } \\
\text { apraxia }\end{array}$ & $\begin{array}{l}\text { Deficit in memory, language, and } \\
\text { executive function }\end{array}$ & $\begin{array}{l}\text { Mild deficits in executive function, } \\
\text { language, and memory }\end{array}$ & $\begin{array}{l}\text { Mild memory } \\
\text { complaints }\end{array}$ \\
\hline Parkinsonism & $\begin{array}{l}\text { Axial rigidity, hypomimia } \\
\text { bradykinesia, and hypophonia }\end{array}$ & Mild unilateral parkinsonism & Mild bradykinesia & No \\
\hline $\begin{array}{l}\text { Ocular motor } \\
\text { symptoms }\end{array}$ & Slow saccadic movements & $\begin{array}{l}\text { Downbeating and torsional } \\
\text { nystagmus }\end{array}$ & $\begin{array}{l}\text { Saccadic intrusions. Bilateral end- } \\
\text { gaze nystagmus }\end{array}$ & $\begin{array}{l}\text { Down-beating } \\
\text { nystagmus }\end{array}$ \\
\hline Treatment & IVIG, IVMP, rituximab, and CTX & IVMP and IVIG & IVMP and plasmapheresis & Prednisone/CTX \\
\hline $\begin{array}{l}\text { Follow-up (mRS } \\
\text { at last visit) }\end{array}$ & $10 \mathrm{mo}(4)$ & $\begin{array}{l}52 \text { mo ( } 4 \text {, at the time of death } \\
\text { from ovarian cancer) }\end{array}$ & $36 \mathrm{mo}(3)$ & $72 \mathrm{mo}(4)$ \\
\hline
\end{tabular}

Abbreviations: CTX = cyclophosphamide; IVIG = IV immunoglobulin; IVMP = IV methylprednisolone; mRS = modified Rankin Scale. 

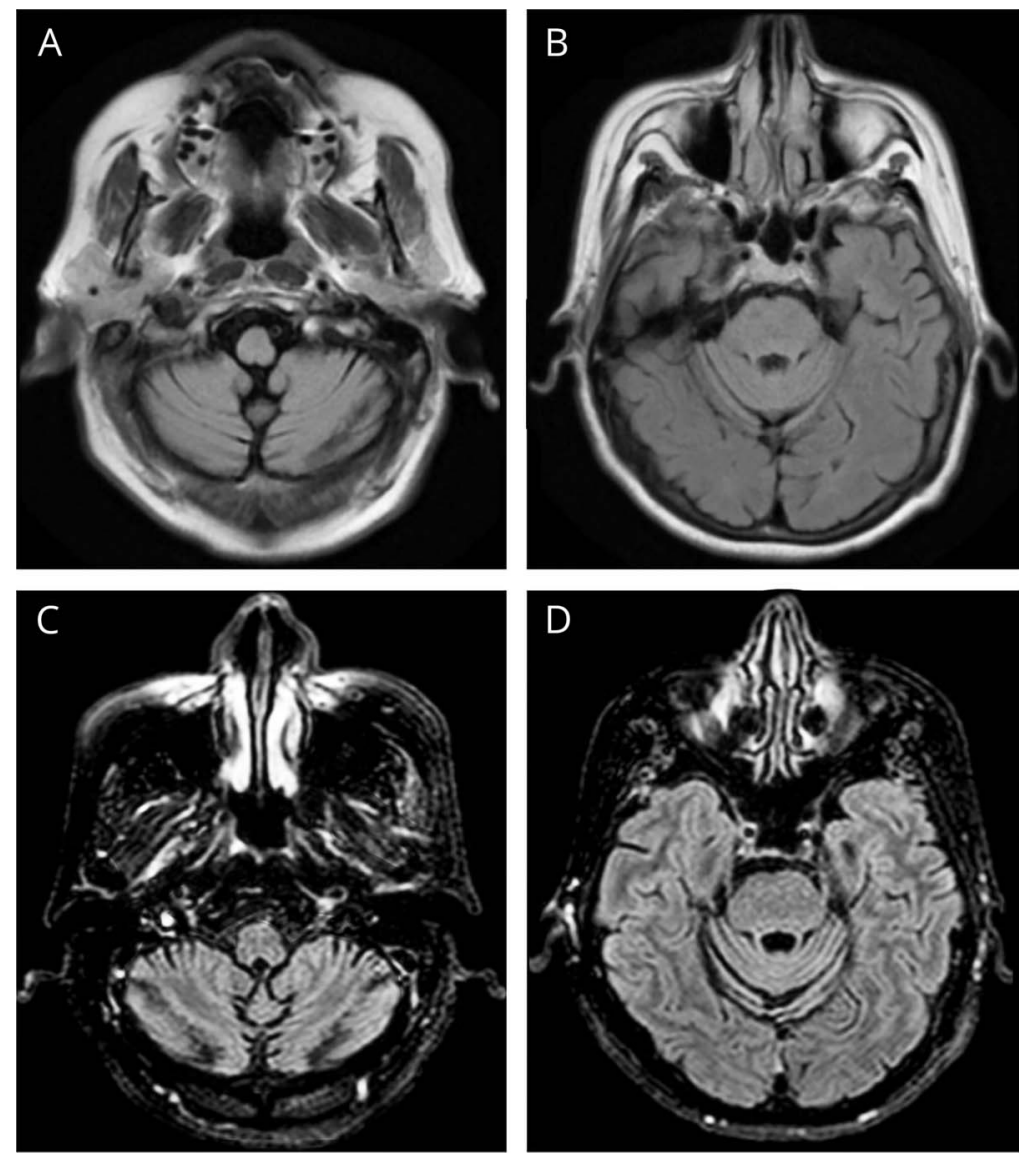

Axial fluid-attenuated inversion recovery (FLAIR) MRI images of the cerebellum at 5 months after onset show minor changes of atrophy in the cerebellar hemispheres (A) and vermis $(B)$ that became more evident in the MRI performed 1 year later (C and D).
GluA1 (1:200, AGP-009, Alomone Labs, Jerusalem, Israel) was incubated in addition to serum of patient 4 , as previously described. After fixation, neurons were incubated with Alexa Fluor 488 goat anti-guinea pig IgG (1:1000, A11073, Thermo Fisher Scientific) and Alexa Fluor 633 goat anti-human IgG (1:1000, A21091, Thermo Fisher Scientific). Cells were then washed, permeabilized, and incubated with anti-PSD95 (1: 200), followed by Alexa Fluor 594 goat anti-rabbit IgG (1: 1000). Cell surface clusters were captured using confocal microscopy (LSM710, Carl Zeiss, Jena, Germany). Images were deconvolved using Huygens Professional version 17.04 (Scientific Volume Imaging, The Netherlands) and quantified using Imaris 8.1 software (Bitplane AG, Zürich, Switzerland).

\section{Data availability}

All data are reported within the article and available anonymized by request from qualified investigators.

\section{Results}

\section{Clinical findings}

The index patient was a 69-year-old man, initially evaluated in July 2019 for an 8-week history of headache, progressive gait instability with frequent falls, and vertical diplopia. On neurologic examination, the patient was bradyphrenic with reduced verbal output, constructive and ideomotor apraxia, and hypophonic and markedly dysarthric speech. Saccadic eye movements were slow and fragmented in all directions of gaze, and he had severe axial rigidity and postural instability. Gait was broad based and required full support. No dysmetria was observed in the limbs, and the rest of the neurologic examination was normal.

Routine blood analysis, EEG, brain and spinal MRI, and 18FGD body PET/CT scan were normal. CSF analysis showed 90 lymphocytes $/ \mathrm{mm}^{3}$ with normal glucose and protein levels. IgG oligoclonal bands were negative. The patient did not benefit from sequential treatments with IV methylprednisolone, immunoglobulins, and rituximab with cyclophosphamide. Over the ensuing months, his neurologic problems worsened progressively, particularly the bradyphrenia, the reduction of verbal output, which became echolalic and monosyllabic, and the gait ataxia.

The demographic and clinical features of the 4 patients with SEL6L2-abs are summarized in the table. All of them were aged $>50$ years (range: $54-69$ years), and 2 were female. The clinical presentation was characterized by progressive walking 

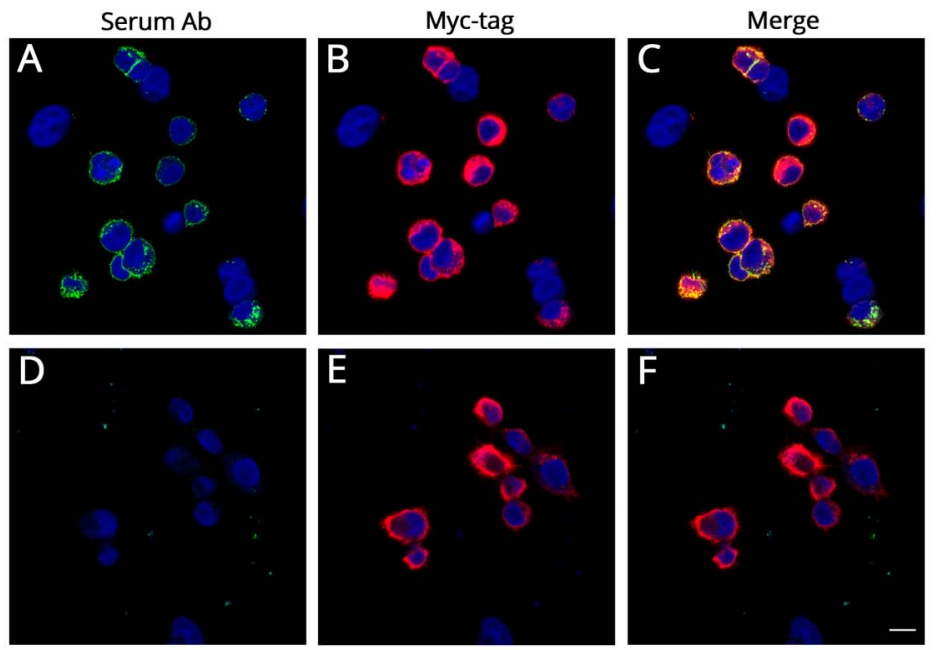

G

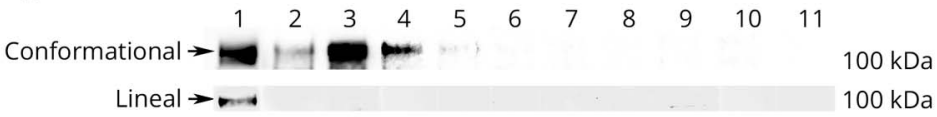

IgG1

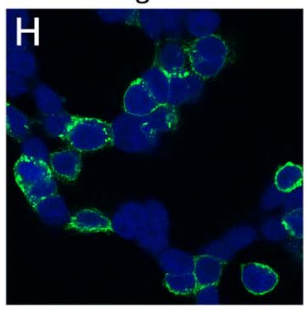

$\operatorname{lgG} 2$

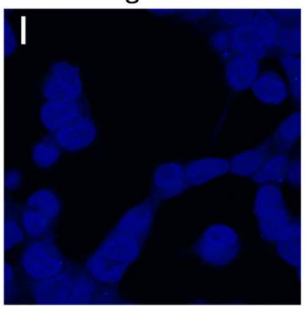

$\operatorname{lgG3}$

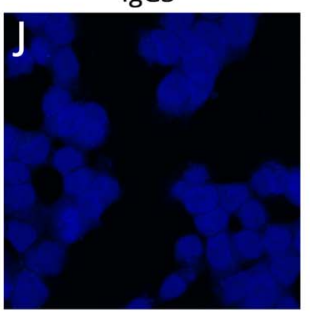

$\operatorname{lgG} 4$

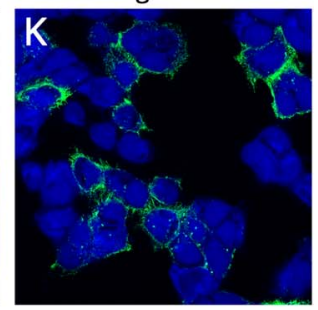

HEK293 cells were transfected to express SEZ6L2 and incubated live, not permeabilized, with a patient's (A-C) or control (D-F) serum. Patient's serum, but not control serum, stained the cell surface of cells (green) that specifically express SEZ6L2, as demonstrated by the Myc-tag antibody (red). Both reactivities are shown merged in C. Nuclei counterstained with 4',6-diamidino-2-phenylindole (DAPI). Scale bar $=10 \mu \mathrm{m}$. (G, upper row): Western blot showing that the 4 patients' serum samples with SEZ6L2ab (lanes 2-5) immunoprecipitated SEZ6L2. Lane 1 shows the immunoprecipitation using the commercial antibody, and lanes 6-9 demonstrate the lack of SEZ6L2 immunoprecipitation with 6 control samples. (G, lower row): Immunoblot strips of cell lysates of SEZ6L2-expressing HEK293 cells under denaturing conditions. None of the patient's serum (lanes 2-5) reacted with the denaturalized SEZ6L2 protein. Strips were also tested with a commercial SEZ6L2-ab (lane 1) and 6 control human sera (lanes 6-11). $(\mathrm{H}-\mathrm{K})$ Example of detection of SEZ6L2-ab IgG subclasses using a HEK293 cell-based assay. This patient's serum had IgG1 and IgG4 SEZ6L2-ab (green reactivity) being the IgG1 subclass immunoreactivity $(\mathrm{H})$ more intense than that of the IgG4 (K). Nuclei counterstained with DAPI. IgG = immunoglobulin G. difficulty (in all 4 patients) associated with postural instability ( 2 patients), dysarthria (2), and mild cognitive impairment (1; not noted by family but found on cognitive testing). The neurologic symptoms had a subacute evolution. All patients showed moderate or substantial disability with a score $\geq 3$ on the modified Rankin Scale in $<5$ months from onset. Patient 3 was also diagnosed with glomerular membranous nephropathy at the same time of the ataxia. Initial evaluation and followup of all patients did not show any malignancy except in patient 2 who was diagnosed with metastatic ovarian cancer 4 years after the onset of cerebellar ataxia.

Neurologic examination during the follow-up showed in all patients cerebellar ataxic gait and dysarthria and limb ataxia in 3. All but patient 4 presented symptoms beyond the cerebellum. Three patients had extrapyramidal symptoms, such as bradykinesia, hypomimia or hypophonia, or mild subcorticaltype cognitive impairment. In addition, 2 patients (patients 2 and 3) developed dysphagia, 1 (patient 3) spastic paraparesis, and another (patient 1) referred vivid nightmares. The combination of parkinsonian and cerebellar symptoms usually raised the possibility of multiple system atrophy, but none of them showed orthostatic hypotension or other signs of dysautonomia.
Brain MRI was normal in patient 1 and showed mild to moderate cerebellar atrophy in the other 3 patients, that worsened over time, without contrast enhancement or other inflammatory features (figure 1). CSF pleocytosis was observed only in patient 1. Despite the initial subacute progressive course, clinical deterioration slowed down or stopped even in the absence of treatment with immunosuppressors, but never improved. Except for patient 1 who was treated $<2$ months from onset, in the remaining 3 patients, the treatment was initiated 23,13 , and 5 months after diagnosis and only for short time periods.

\section{Immunologic studies and characterization of the antigen}

Immunoprecipitation of granular cells of the cerebellum with the CSF of patient 1 revealed 9 unique peptides containing the $9 \%$ of the protein sequence of the SEZ6L2 (Accession number Q6UXD5). The CBA using HEK293 cells transfected with SEZ6L2 identified 3 additional patients out of 95 with uncharacterized neuropil antibodies. None of the sera from the 10 healthy subjects or the 331 patients with diverse neurologic disorders were positive for SEZ6L2-abs in the CBA (figure 2, A-F). To confirm the specificity of the CBA assay, the 4 sera with SEZ6L2-abs and 6 randomly selected controls were used for immunoprecipitation of SEZ6L2- 
expressing HEK293 cells. All 4 samples but none of the controls immunoprecipitated SEZ6L2 (figure 2G).

The serum of the 4 patients with SEZ6L2-abs showed the same pattern of reactivity in immunohistochemical studies of the rat brain (figure 3). Immunoreactivity was more intense in the neuropil of the hippocampus and in the molecular layer and synaptic buttons of the granular layer of the cerebellum. All samples also labeled the membrane of live neurons in culture (figure $3 \mathrm{~A}$ ), indicating that antibodies recognized an extracellular epitope of SEZ6L2. To study whether the epitope recognized by SEZ6L2abs was linear or conformational, we incubated patients' serums with immunoblot strips containing whole-cell lysates of SEZ6L2expressing HEK293 cells under denaturing conditions. None of the patient's serum reacted with the denaturalized protein, whereas a commercial antibody against the extracellular part of the protein did recognize the linear epitope, indicating that the human SEZ6L2-abs identify conformational epitopes (figure 2G).

Analysis of serum IgG subclasses showed that all sera had IgG4 immunoreactivity. IgG1 SEZ6L2-abs were identified in 3 patients (patient 3 was negative), and it was the predominant IgG subclass in patients 1 and 4. None of the patients' serum showed reactivity with IgG2 or IgG3 subclasses (figure 2, H-K). CSF IgG subclasses were similar to those identified in serum.

\section{SEZ6L2 antibody effects on live rat hippocampal cultures}

Total SEZ6L2 surface clusters or synaptic SEZ6L2 clusters were not reduced after 24 or 72 hours of incubation with patient's CSF compared with control CSF (figure 4). In parallel, neurons treated with CSF harboring NMDAR antibodies showed a dramatic decrease of total cell surface and synaptic NMDAR clusters at 24 and 72 hours, as expected (figure 4). Treatment with SEZ6L2-abs positive CSF during 72 hours and posterior triple immunostaining of GluA1, PSD95, and SEZ6L2 showed no antibody derived alterations on total or synaptic GluA1 (figure $1 \mathrm{~S}$ in supplemental material, links.lww.com/NXI/A344). Similarly, colocalization of SEZ6L2 and GluA1 was not altered after the treatment (figure 1S).

\section{Discussion}

We describe the clinical features of 4 new patients with SEZ6L2-abs and several novel immunologic findings including the presence of IgG4 SEZ6L2-abs in 4 patients that was the predominant subtype in 2 and the lack of effects of the antibodies on the surface levels of SEZ6L2 or GluA1 in rat hippocampal neurons. We also confirm that SEZ6L2-abs recognize conformational epitopes in the extracellular region, suggesting their potential pathogenic role, as supported by immunolabeling of live neuronal cultures and lack of immunoblot reactivity with SEZ6L2 denaturated protein.

Our study confirms the association of SEZ6L2-abs with cerebellar ataxia. Besides the index patient, the other 3 patients were selected among a group of 95 patients with different clinical syndromes who had in common the presence of uncharacterized serum neuropil antibodies. This methodological approach excluded the possibility of clinical selection bias. The clinical features of our 4 patients along with those of 2 previously reported cases show that the main manifestation is a subacute onset of gait ataxia and dysarthria that progresses over several months and later stabilizes.

Figure 3 Immunoreactivity of SEZ6L2-ab in hippocampal neurons and rat brain sections
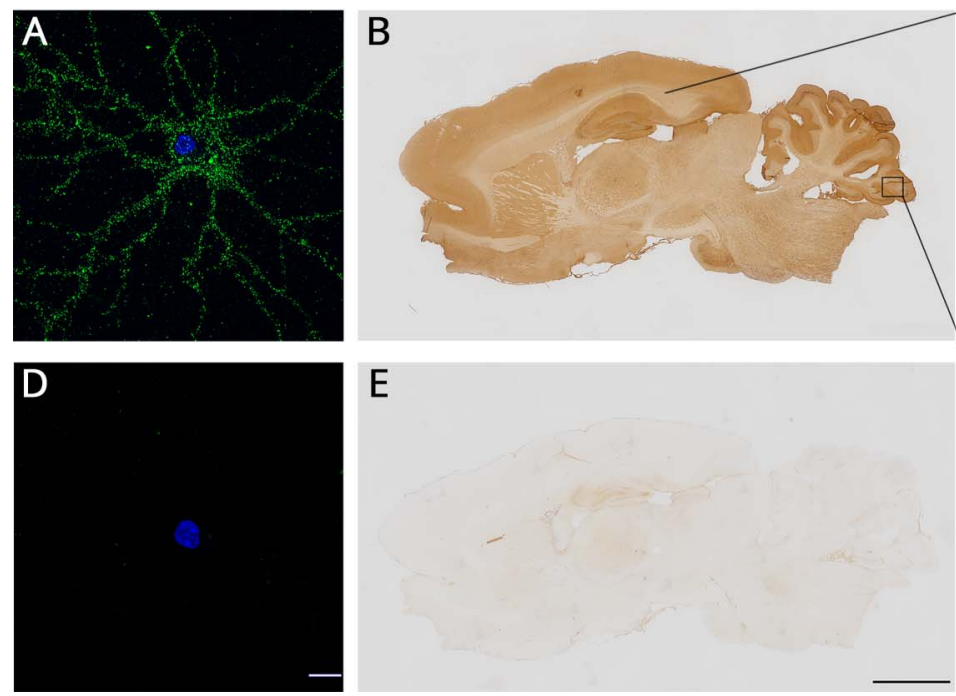

E
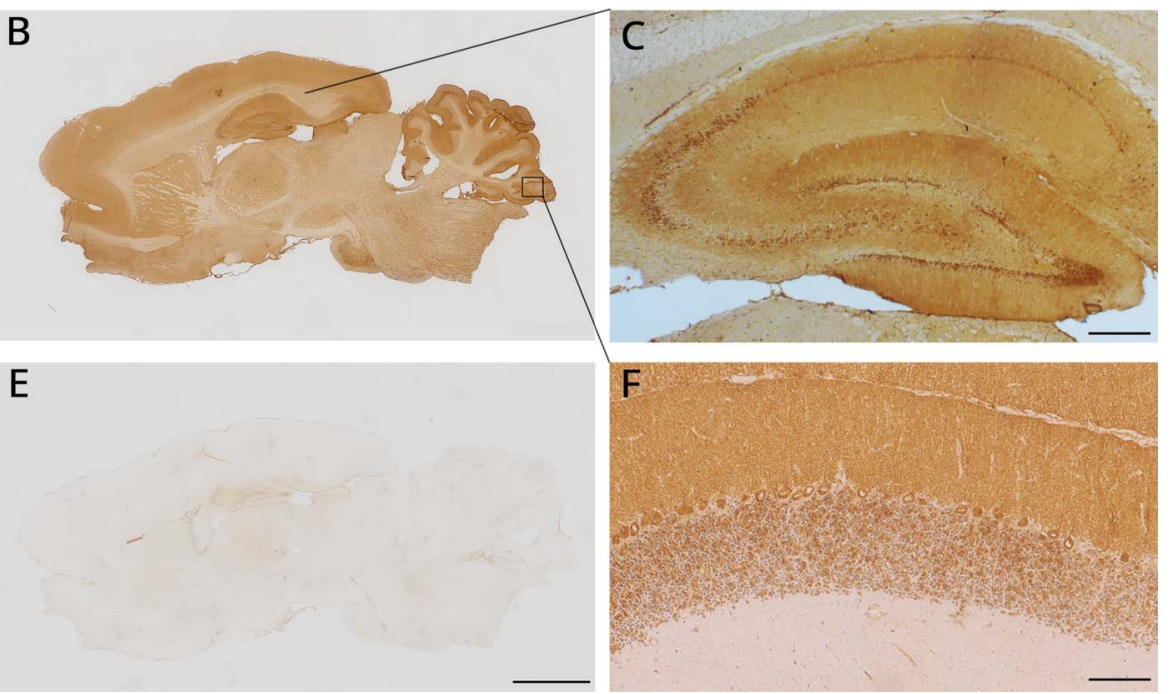

Culture of rat hippocampal neurons incubated (nonpermeabilized) with a patient's serum with SEZ6L2-ab showing intense reactivity with the cell surface antigen (A), whereas a control serum is negative (D). (B) Sagittal section of the rat brain immunostained with a patient's CSF with SEZ6L2-ab: there is a diffuse staining of the neuropil, which is not seen when rat brain sections are incubated with a control CSF (E). Immunoreactivity was particularly robust in the hippocampus (C) and cerebellum (F) where there was diffuse staining of the molecular layer and synaptic glomerula of the granular cell layer. Scale bars in $A$ and $B=10 \mu \mathrm{m}, \mathrm{B}$ and $\mathrm{D}=2000 \mu \mathrm{m}, \mathrm{E}=500 \mu \mathrm{m}$, and $\mathrm{F}=50$. 
Figure 4 SEZ6L2-abs do not decrease SEZ6L2 clusters on neuronal surface
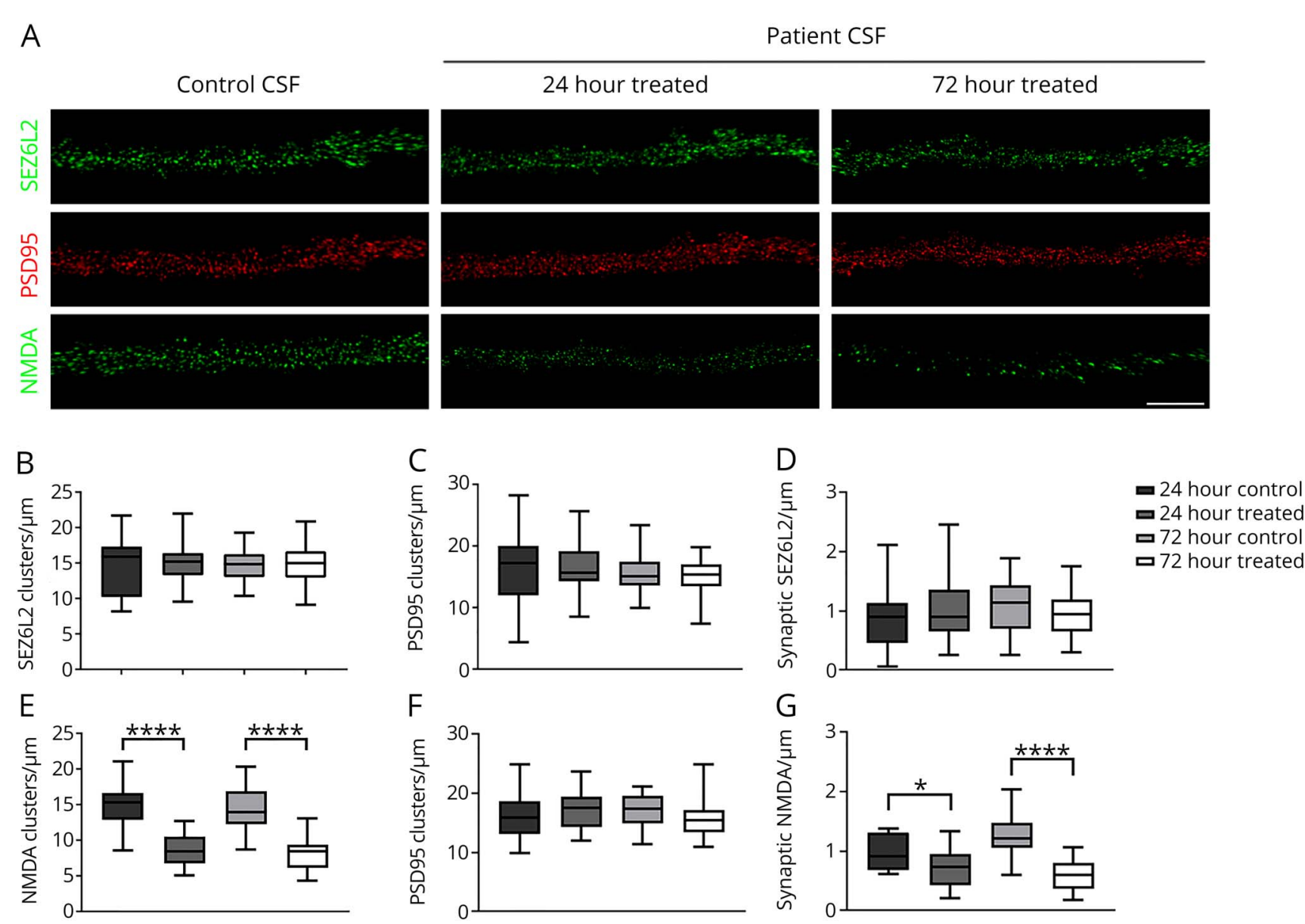

(A) Immunofluorescence on hippocampal neurons treated for 72 hours with CSF control and with SEZ6L2-ab or NMDAR-ab (bottom panels). SEZ6L2-ab, unlike NMDAR-ab, did not affect the surface cluster density of the antigen. Scale bar $=4 \mu \mathrm{m}$. Quantification of total (B) and synaptic (D) SEZ6L2 and PSD95 clusters (C) after treatment with a SEZ6L2-ab-positive or control CSF for 24 hours or 72 hours. (E-G) The same experiment to evaluate density of NMDAR clusters after

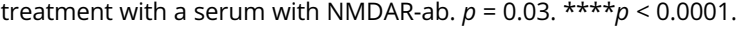

Unlike patients with paraneoplastic cerebellar degeneration or acute postinfectious cerebellitis, the cerebellar syndrome was not isolated, and mild cognitive impairment, extrapyramidal symptoms, hypomimia, bradykinesia, and postural instability were also present. ${ }^{1}$ Response to immunotherapy is difficult to assess as the diagnosis of SEZ6L2-abs was performed in retrospect, but none of our patients improved. One could argue that immunotherapy was given late in the course of the disease, but actually in the index patient, the diagnosis was made only a few months after the onset of the ataxia, and intense immunotherapy was ineffective. Thus, based on these cases and those previously reported with different antibodies against surface antigens, these cerebellar disorders seem to have a poorer prognosis than autoimmune encephalitis associated with cell surface antibodies, probably due to the loss of Purkinje cells in the cerebellum (table $1 \mathrm{~S}$ in supplemental material, links.lww.com/NXI/A344). ${ }^{14,15}$

Our findings demonstrate that SEZ6L2-abs do not cause internalization of SEZ6L2 in cultures of live neurons. The inability of SEZ6L2-abs to cross-link the antigen and induce internalization could potentially be explained by the distribution of SEZ6L2 in the neuronal membrane preventing the cross-linking or more likely because the functional effects of SEZ6L2-abs are mediated by antibodies of the IgG4 subclass, which are functionally monovalent and therefore unable to crosslink the target. ${ }^{16}$ According to the later possibility, our study shows that all 4 SEZ6L2-ab-positive sera contained IgG4 antibodies, although this subtype was predominant in only 2 patients. However, the lack of predominance of an IgG subtype does not necessarily mean that it is responsible for the antibody pathogenicity. For example, in anti-IgLON5 disease, IgG4 antibodies are predominant in the majority of patients, but in primary cultures of neurons, the IgG1 IgLON5 antibodies are responsible for an irreversible decrease of cell surface IgLON5 clusters in a time-dependent manner without affecting the number of excitatory synapses. 17

The lack of internalization of SEL6L2 by patients' antibodies on cultured live neurons favors a functional pathogenic role of the IgG4 subclass. Unlike IgG1, IgG4 antibodies more often interfere with normal protein-protein interactions of the target antigen. ${ }^{18}$ This is the case of myasthenia in which in an experimental animal model, IgG4 but not IgG1-3 muscle- 
specific kinase (MuSK) antibodies were able to transfer the neuromuscular junction dysfunction. ${ }^{19}$ In line with this possibility, a previous study showed that SEZ6L2-ab from the first reported patient impaired the interaction between the GluA1 subunit of the AMPAR and SEZ6L2 affecting the GluA1 signal transduction. ${ }^{9}$ However, these studies were conducted in HELA cells transfected with the extracellular domain of SEZ6L2 and GluA1. Our study in cultures of live neurons, a more physiologic system where the full-length SEZ6L2 protein is expressed and folded in its native state, did not provide clues for the pathophysiology. It showed no internalization of SEZ6L2, but blocking of the interaction between SEZ6L2 and GluAlpossible. For example, in MuSK myasthenia gravis IgG4 serum antibodies block the interaction between MuSK and low-density lipoprotein receptor-related protein 4, but do not necessarily show internalization of MuSK. ${ }^{20}$

The findings of our study are important in helping to recognize the syndrome associated with SEZ6L2-abs. Although all patients had a subacute presentation of symptoms, and case 1 had CSF pleocytosis, this disorder does not appear to manifest with features of inflammation in the brain MRI or CSF that may suggest an autoimmune-mediated ataxia. Pending of the description of more patients, the combination of cerebellar gait ataxia, dysarthria, and mild manifestations of parkinsonism appear to be the core symptoms of this novel autoimmune cerebellar ataxia. Although the syndrome does not seem to respond to immunotherapy, prompt diagnosis and treatment should be considered. This approach may lead to results similar to those seen in patients with cerebellar ataxia and mGluR1 antibodies, that is, patients who improved or stabilized after immunotherapy were those who were more promptly treated. ${ }^{21}$

\section{Acknowledgment}

The proteomics analyses were performed in the CRG/UPF Proteomics Unit, which is part of the ProteoRed, PRB3, and is supported by grant PT17/0019, of the PE I+D+i 2013-2016, funded by ISCIII and ERDF. The authors thank Dr. Maarten Titulaer (Erasmus University Medical Center, Rotterdam, Netherlands), Dr. Raquel Sámchez-Valle, Dr. Yarko Compta, and Dr. Fina Martí (Hospital Clinic de Barcelona) who sent us samples and clinical data to be used as negative controls in this study. The authors thank Mercedes Alba, Esther Aguilar, and Eva Caballero for their excellent technical work.

\section{Study funding}

This study was supported in part by Plan Nacional de I+D+I and cofinanced by the ISCIII-Subdirección General de Evaluación y Formento de la Investigación Sanitaria - and the Fondo Europeo de Desarrollo Regional (ISCIII-FEDER; PI1800067, LS; 17/00234, J. Dalmau). M. Guasp is a recipient of a Resident Award "Josep Font," granted by Hospital Clínic de Barcelona, Research, Innovation and Education Departments. $\mathrm{J}$. Planagumà is the recipient of a grant Pla estratègic de recerca $\mathrm{i}$ innovació en salut (PERIS SLT002/16/00346) and receives funding by Fundació Cellex (J. Dalmau). M.D. Geschwind was supported by the US NIH, National Institute of Aging (NIH/
NIA) grants R01-AG031189, R01-AG062562, and R56AG055619 and the Michael J. Homer Family Fund.

\section{Disclosure}

J. Landa, M. Guasp, M. Petit-Pedrol, E. Martínez-Hernández, J. Planagumà, R. Ruiz-García, L. García-Fernández, L. RamirezGómez, and L. Sabater report no disclosures. A. Saiz reports compensation for consulting services and speaker honoraria from Bayer Schering, Merck Serono, Biogen Idec, SanofiAventis, Teva Pharmaceutical Industries Ltd, Novartis, and Roche. F. Graus receives royalties from Euroimmun for the use of IgLON5 and honoraria for assistant editor of MedLink Neurology. J. Dalmau receives royalties from Athena Diagnostics for the use of $\mathrm{Ma} 2$ as an autoantibody test and from Euroimmun for the use of NMDA, GABAB receptor, GABAA receptor, DPPX and IgLON5 as an autoantibody test. J. Verschuuren receives financial support from the Target-to-B consortium and Prinses Beatrix Spierfonds and has been involved in trials or consultancies for Argenx, Alexion, and Rapharma. He is coinventor on patent applications based on MuSK-related research. The LUMC received royalties from IBL. The author is a member of the European Reference Network for Rare Neuromuscular Diseases [ERN EURO-NMD]. R. Saunders-Pullman is funded by NIH U01-NS107016 and the Bigglesworth Family Foundation. M.D. Geschwind has consulted for Adept Field Consulting, Anderson Boutwell Traylor Bioscience Pharma Partners LLC (BPP), Blade Therapeutics Inc., Grand Rounds Inc., LifeSci Capital LLC, Maupin Cox Legoy LLC, Microvention Terumo, Quest Diagnostics, and Trinity Partners LLC and received honorarium for noncommercial entity speaking. Go to Neurology.org/NN for full disclosures.

\section{Publication history}

Received by Neurology: Neuroimmunology \& Neuroinflammation July 13, 2020. Accepted in final form September 21, 2020.

\begin{tabular}{lll} 
Appendix Authors & \\
\hline Name & Location & Contribution \\
\hline Jon Landa, MSc & $\begin{array}{l}\text { IDIBAPS, } \\
\text { Barcelona, Spain }\end{array}$ & $\begin{array}{l}\text { Drafted the first version of the } \\
\text { manuscript; major role in the } \\
\text { study of antibody effects; } \\
\text { analyzed the data; and revised } \\
\text { the manuscript for intellectual } \\
\text { content }\end{array}$
\end{tabular}

\begin{tabular}{lll}
\hline Mar Guasp, MD & $\begin{array}{l}\text { IDIBAPS, } \\
\text { Barcelona, Spain }\end{array}$ & $\begin{array}{l}\text { Drafted the first version of the } \\
\text { manuscript; analyzed the data; } \\
\text { acquisition of clinical data; and } \\
\text { revised the manuscript for } \\
\text { intellectual content }\end{array}$ \\
\hline $\begin{array}{l}\text { Mar Petit- } \\
\text { Pedrol, PhD }\end{array}$ & $\begin{array}{l}\text { IDIBAPS, } \\
\text { Barcelona, Spain }\end{array}$ & $\begin{array}{l}\text { Immunoprecipitation studies; } \\
\text { analysis and interpretation of } \\
\text { the data; and revised the } \\
\text { manuscript for intellectual } \\
\text { content }\end{array}$ \\
\hline $\begin{array}{l}\text { Eugenia } \\
\text { Martínez- } \\
\text { Hernández, MD, } \\
\text { PhD }\end{array}$ & $\begin{array}{l}\text { Hospital Clínic and } \\
\text { IDIBAPS, }\end{array}$ & $\begin{array}{l}\text { Acquisition of clinical data and } \\
\text { revised the manuscript for } \\
\text { intellectual content }\end{array}$ \\
\hline
\end{tabular}


Appendix (continued)

\begin{tabular}{|c|c|c|}
\hline Name & Location & Contribution \\
\hline $\begin{array}{l}\text { Jesús } \\
\text { Planagumà, } \\
\text { PhD }\end{array}$ & $\begin{array}{l}\text { IDIBAPS, } \\
\text { Barcelona, Spain }\end{array}$ & $\begin{array}{l}\text { Analyzed the data and revised } \\
\text { the manuscript }\end{array}$ \\
\hline $\begin{array}{l}\text { Albert Saiz, MD, } \\
\text { PhD }\end{array}$ & $\begin{array}{l}\text { Hospital Clínic and } \\
\text { IDIBAPS, } \\
\text { Barcelona, Spain }\end{array}$ & $\begin{array}{l}\text { Acquisition of clinical data and } \\
\text { revised the manuscript for } \\
\text { intellectual content }\end{array}$ \\
\hline $\begin{array}{l}\text { Raquel Ruiz- } \\
\text { García, PhD }\end{array}$ & $\begin{array}{l}\text { Hospital Clínic, } \\
\text { Barcelona, Spain }\end{array}$ & $\begin{array}{l}\text { Acquisition of clinical data and } \\
\text { revised the manuscript for } \\
\text { intellectual content }\end{array}$ \\
\hline $\begin{array}{l}\text { Lorena García- } \\
\text { Fernández, MD }\end{array}$ & $\begin{array}{l}\text { Hospital General } \\
\text { San Jorge, Huesca, } \\
\text { Spain }\end{array}$ & $\begin{array}{l}\text { Acquisition of clinical data and } \\
\text { revised the manuscript for } \\
\text { intellectual content }\end{array}$ \\
\hline $\begin{array}{l}\text { Jan } \\
\text { Verschuuren, } \\
\text { MD, PhD }\end{array}$ & $\begin{array}{l}\text { Leiden University, } \\
\text { Leiden, The } \\
\text { Netherlands }\end{array}$ & $\begin{array}{l}\text { Acquisition of clinical data and } \\
\text { revised the manuscript for } \\
\text { intellectual content }\end{array}$ \\
\hline $\begin{array}{l}\text { Rachel } \\
\text { Saunders- } \\
\text { Pullman, MD, } \\
\text { MPH }\end{array}$ & $\begin{array}{l}\text { Mount Sinai Beth } \\
\text { Israel, NY }\end{array}$ & $\begin{array}{l}\text { Acquisition of clinical data and } \\
\text { revised the manuscript for } \\
\text { intellectual content }\end{array}$ \\
\hline $\begin{array}{l}\text { Liliana Ramirez- } \\
\text { Gómez, MD }\end{array}$ & $\begin{array}{l}\text { Massachusetts } \\
\text { General Hospital, } \\
\text { Boston }\end{array}$ & $\begin{array}{l}\text { Acquisition of clinical data and } \\
\text { revised the manuscript for } \\
\text { intellectual content }\end{array}$ \\
\hline $\begin{array}{l}\text { Michael D. } \\
\text { Geschwind, MD, } \\
\text { PhD }\end{array}$ & $\begin{array}{l}\text { Memory and Aging } \\
\text { Center, San } \\
\text { Francisco, CA }\end{array}$ & $\begin{array}{l}\text { Acquisition of clinical data and } \\
\text { revised the manuscript for } \\
\text { intellectual content }\end{array}$ \\
\hline $\begin{array}{l}\text { Josep Dalmau, } \\
\text { MD, PhD }\end{array}$ & $\begin{array}{l}\text { IDIBAPS, } \\
\text { Barcelona, Spain }\end{array}$ & $\begin{array}{l}\text { Acquisition of clinical data; } \\
\text { analysis and interpretation of the } \\
\text { data; and revised the manuscript } \\
\text { for intellectual content }\end{array}$ \\
\hline $\begin{array}{l}\text { Lidia Sabater, } \\
\text { PhD }\end{array}$ & $\begin{array}{l}\text { IDIBAPS, } \\
\text { Barcelona, Spain }\end{array}$ & $\begin{array}{l}\text { Analysis and interpretation of } \\
\text { the data; designed and } \\
\text { conceptualized the study; and } \\
\text { revised the manuscript for } \\
\text { intellectual content }\end{array}$ \\
\hline $\begin{array}{l}\text { Francesc Graus, } \\
\text { MD, PhD }\end{array}$ & $\begin{array}{l}\text { IDIBAPS, } \\
\text { Barcelona, Spain }\end{array}$ & $\begin{array}{l}\text { Drafted the last version of the } \\
\text { manuscript; designed and } \\
\text { conceptualized the study; } \\
\text { acquisition of clinical data; } \\
\text { analysis and interpretation of the } \\
\text { data; and revised the manuscript } \\
\text { for intellectual content }\end{array}$ \\
\hline
\end{tabular}

\section{References}

1. Joubert B, Rostásy K, Honnorat J. Immune-mediated ataxias. Handb Clin Neurol 2018;155:313-332.

2. Dalmau J, Geis C, Graus F. Autoantibodies to synaptic receptors and neuronal cell surface proteins in autoimmune diseases of the central nervous system. Physiol Rev 2017;97:839-887.

3. Yaguchi H, Yabe I, Takahashi H, et al. Identification of anti-Sez612 antibody in a patient with cerebellar ataxia and retinopathy. J Neurol 2014;261:224-226.

4. Borsche M, Hahn S, Hanssen H, Münchau A, Wandinger KP, Brüggemann N. Sez612antibody-associated progressive cerebellar ataxia: a differential diagnosis of atypical parkinsonism. J Neurol 2019;266:522-524.

5. Ishikawa N, Daigo Y, Takano A, et al. Characterization of SEZ6L2 cell-surface protein as a novel prognostic marker for lung cancer. Cancer Sci 2006;97:737-745.

6. Miyazaki T, Hashimoto K, Uda A, et al. Disturbance of cerebellar synaptic maturation in mutant mice lacking BSRPs, a novel brain-specific receptor-like protein family. FEBS Lett 2006;580:4057-4064.

7. Nash A, Aumann TD, Pigoni M, et al. Lack of Sez6 family proteins impairs motor functions, short-term memory, and cognitive flexibility and alters dendritic spine properties. Cereb Cortex 2020;30:2167-2184.

8. Yaguchi H, Yabe I, Takahashi H, et al. Sez6l2 regulates phosphorylation of ADD and neuritogenesis. Biochem Biophys Res Commun 2017;494:234-241.

9. Yaguchi H, Yabe I, Takahashi H, et al. Anti-Sez6l2 antibody detected in a patient with immune-mediated cerebellar ataxia inhibits complex formation of GluR1 and Sez612. J Neurol 2018;265:962-965.

10. Sabater L, Xifró X, Saiz A, Alberch J, Graus F. Analysis of antibodies to neuronal surface antigens in adult opsoclonus-myoclonus. J Neuroimmunol 2008;196: 188-191.

11. Ances BM, Vitaliani R, Taylor RA, et al. Treatment-responsive limbic encephalitis identified by neuropil antibodies: MRI and PET correlates. Brain 2005;128: 1764-1777.

12. Dalmau J, Lancaster E, Martinez-Hernandez E, Rosenfeld MR, Balice-Gordon R. Clinical experience and laboratory investigations in patients with anti-NMDAR encephalitis. Lancet Neurol 2011;10:63-74.

13. Hara M, Ariño H, Petit-Pedrol M, et al. DPPX antibody-associated encephalitis Main syndrome and antibody effects. Neurology 2017;88:1340-1348.

14. Fukuda T, Motomura M, Nakao Y, et al. Reduction of P/Q-type calcium channels in the postmortem cerebellum of paraneoplastic cerebellar degeneration with LambertEaton myasthenic syndrome. Ann Neurol 2003;53:21-28.

15. Coesmans M, Sillevis Smitt PA, Linden DJ, et al. Mechanisms underlying cerebellar motor deficits due to mGluR1-autoantibodies. Ann Neurol 2003;53: 325-336.

16. Aalberse RC, Schuurman J. IgG4 breaking the rules. Immunology 2002;105:9-19.

17. Sabater L, Planagumà J, Dalmau J, Graus F. Cellular investigations with human antibodies associated with the anti-IgLON5 syndrome. J Neuroinflammation 2016; 13:226-237.

18. Huijbers MG, Querol LA, Niks EH, et al. The expanding field of IgG4-mediated neurological autoimmune disorders. Eur J Neurol 2015;22:1151-1161.

19. Klooster R, Plomp JJ, Huijbers MG, et al. Muscle-specific kinase myasthenia gravis IgG4 autoantibodies cause severe neuromuscular junction dysfunction in mice. Brain 2012;135:1081-1101.

20. Huijbers MG, Zhang W, Klooster R, et al. MuSK IgG4 autoantibodies cause myasthenia gravis by inhibiting binding between MuSK and Lrp4. Proc Natl Acad Sci U S A 2013;110:20783-20788.

21. Christ M, Müller T, Bien C, Hagen T, Naumann M, Bayas A. Autoimmune encephalitis associated with antibodies against the metabotropic glutamate receptor type 1: case report and review of the literature. Ther Adv Neurol Disord 2019;12: 1756286419847418 . 


\section{Neurology \\ Neuroimmunology \& Neuroinflammation}

\section{Seizure-related 6 homolog like 2 autoimmunity: Neurologic syndrome and antibody effects}

Jon Landa, Mar Guasp, Mar Petit-Pedrol, et al.

Neurol Neuroimmunol Neuroinflamm 2021;8;

DOI 10.1212/NXI.0000000000000916

This information is current as of November 3, 2020

\section{Updated Information \& \\ Services}

References

Subspecialty Collections

Permissions \& Licensing

Reprints including high resolution figures, can be found at:

http://nn.neurology.org/content/8/1/e916.full.html

This article cites 21 articles, 1 of which you can access for free at: http://nn.neurology.org/content/8/1/e916.full.html\#\#ref-list-1

This article, along with others on similar topics, appears in the following collection(s):

All Clinical Neurology

http://nn.neurology.org//cgi/collection/all_clinical_neurology

Autoimmune diseases

http://nn.neurology.org//cgi/collection/autoimmune_diseases

Gait disorders/ataxia

http://nn.neurology.org//cgi/collection/gait_disorders_ataxia

Information about reproducing this article in parts (figures,tables) or in its entirety can be found online at:

http://nn.neurology.org/misc/about.xhtml\#permissions

Information about ordering reprints can be found online:

http://nn.neurology.org/misc/addir.xhtml\#reprintsus

Neurol Neuroimmunol Neuroinflamm is an official journal of the American Academy of Neurology.

Published since April 2014, it is an open-access, online-only, continuous publication journal. Copyright

Copyright $\odot 2020$ The Author(s). Published by Wolters Kluwer Health, Inc. on behalf of the American

Academy of Neurology.. All rights reserved. Online ISSN: 2332-7812.

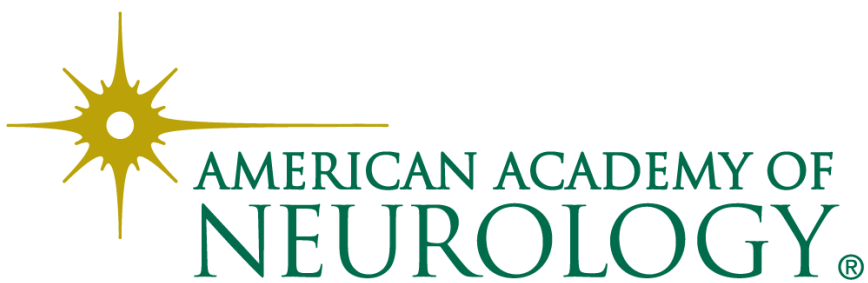

